\title{
Dynamics of phytophage invasions and peculiarities of their phenology in the parks of the south coast of the Crimea
}

\author{
A.K. Sharmagiy", E.B. Balykina, N.N. Trikoz, D.A. Korzh, and E.V. Yatskova \\ Federal State Budgetary Institution of Science "Nikitsky Botanical Garden - National Scientific \\ Center", Yalta, the Republic of Crimea, Russia
}

\begin{abstract}
The analysis of the modern process of phytophagous insect invasion on the South Coast of the Crimea showed that since the beginning of the active introduction of woody and shrubby plants of foreign breeding for the 18-year period from 2002 to 2020 . Fifteen harmful species previously unregistered in the region have been identified. Since 2008, one or two new species have been identified annually, which has led to significant changes in the taxonomic structure of the phytophagous complex in the parks of the South Coast of the Crimea. Invasive phytophages are represented by five orders, of which $26.4 \%$ are species of the order Homoptera, $19.8 \%$ are species of the orders Lepidoptera, Coleoptera and Hymenoptera, 14.2\% are phytophages of the order Diptera. It is established that nine species are monophages, three species are oligophages, and three species are polyphages. Icerya purchasi Mask., Cydalima perspectalis Walker, Ceroplastes japonicus Green, Chrysolina americana L., Cameraria ohridella Deschka\&Dimic, Bactrocera oleae Rossi and Paysandisia archon Burmeister are the greatest threat to plantings. The terms of detection and the area on the territory of the Crimea, the range of forage plants, the degree of harmfulness, the frequency of occurrence is established, and data on the phenology of the most important species are presented.
\end{abstract}

\section{Introduction}

On the South Coast of the Crimea, there are about 100 large and small parks with a total area of 1.5 thousand hectares. Many of them are parks-monuments of great value and are subject to state protection. Park biocenosis is characterized by species and age diversity. In the largest parks, there are from 100 to 200 species and forms of trees and shrubs. [2, 6]

Many factors affect the durability and decorative quality of plants, including the damage caused by pests. The entomo-faunistic complex is formed from local and imported species. Its structure depends on the species composition of the plantings, especially on the proportion of introduced plants, their age, and the degree of anthropogenic load. Pests introduced together with plants, devoid of natural enemies, can multiply en masse and lead to plants death. Due to the predominance of evergreen trees and shrubs, phytophages from the families: Coccoidea, Diaspididae, Psyllidae, Aphidinea, Eriophyidae are the most dangerous on the

${ }^{*}$ Corresponding author: zaschitanbs@rambler.ru 
South Coast of the Crimea, as well as representatives of the order Lepidoptera. With the import of new plants, the species composition of phytophages has changed, among which invasive species with high bio-potential, ecological plasticity and aggressiveness pose a serious problem for biodiversity. Most of them are serious pests of park, forest, and fruit crops. The emergence of new pest species has led to a change in the taxonomic structure of the park biocenosis.

The purpose of the study is to analyze the modern phytophage invasion process in the conditions of the South Coast of the Crimea, to identify the dominant species, and to study their phenology features.

\section{Location and methods of research}

The research was carried out in the period from 2002 to 2020 in the parks of the South Coast of the Crimea: the arboretum of the Nikitsky Botanical Garden, the parks of the sanatoriums "Ai-Danil", "Gurzufsky", "Dulber", "Aivazovskoye", the Alupka Palace and Park MemorialEstate. The specific and quantitative composition of phytophages was determined by route surveys with a frequency of 1 time in 7-10 days. The following methods were used during the surveys: shaking off, visual inspection, pheromone traps, and catching bands. The degree of plant introduction was determined on a three-point scale: 1 - poor - up to $40 \%$ of damaged organ surface; 2 - medium - up to $60 \%$ of damaged organ surface; 3 - strong - from $60 \%$ and more.

The summer dynamics of the $C$. ohridella was monitored using glue traps with a pheromone dispenser manufactured by FSBI VNIIKR. The traps were hung close to the trees of Aésculus hippocastanum L., the captured males of $C$. ohridella were counted 1 time every 7-10 days.

\section{Results and discussion}

As a result of a long-term analysis of the phytosanitary condition of the parks of the South Coast of Crimea, its instability was revealed, which is expressed in periodic sharp increases in the number of individual pests, disappearance of others, constant changes of the dominant species that occur under the influence of interspecific competition, weather and climatic factors, anthropogenic and pesticide loads, the activity of entomoacariphages and passive migration. Many phytophages belong to subtropical species that were able to adapt quickly in a mild climate. Most are found on ornamental crops, but there are species that inhabit different biotopes. For example, I. purchasi parasitizes on fruit, subtropical and coniferous crops, both on the field and under cover, and C. japonicus inhabits equally ornamental and subtropical fruit crops (Diospyros kaki L. f.). [7]

It was found that during the period from 2002 to 2020, the taxonomic structure of the phytophagan complex in the parks of the South Coast of the Crimea underwent significant changes mainly due to the introduction of introduced species. Invasive species are represented by five orders, of which $26.4 \%$ are species of the order Homoptera, $19.8 \%$ are species of the orders Lepidoptera, Coleoptera and Hymenoptera, $14.2 \%$ are phytophages of the order Diptera (Figure 1). With the appearance of introduced species, the species composition and the number of native pest species have changed. So, with the propagation of C. perspectalis, other boxwood pests - Monarthropalpus flavus Schrank., Psylla buxi L. and Eriococcus buxi Fonsc - are practically not found or are present in the form of single foci. On sycamores, such species as Edvardsiana platani A. and Phyllonorycter platani Staudinger have disappeared in connection with the appearance of Corythucha ciliata Say. 


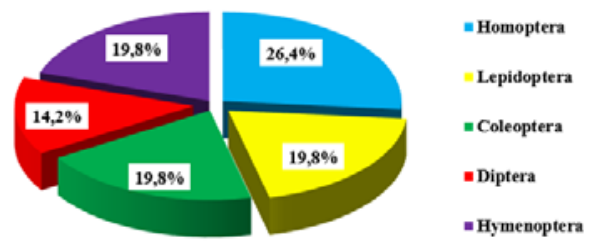

Fig. 1. Taxonomic structure of invasive phytophage species of park cenoses of the South Coast of Crimea, 2020.

The analysis of the modern process of phytophagous insects invasion in the region showed that since the beginning of the active introduction of woody and shrubby plants of foreign breeding since the beginning of the 2000s, 15 phytophages not previously registered in the territory of the Crimea have been identified over an 18-year period, of which 9 species are monophages, 3 species are oligophages and 3 species are polyphages. At the same time, since 2008, 1-2 new species have been registered annually (Table 1). I. purchasi, $C$. perspectalis, C. japonicus, $C$. americana, $C$. ohridella, B. oleae and $P$. archon are greatest threats to plantings.

Table 1. Dynamics of phytophage invasions on the South Coast of the Crimea

\begin{tabular}{|c|c|c|c|c|}
\hline No. & Type of pest & $\begin{array}{c}\text { Year of } \\
\text { detection }\end{array}$ & $\begin{array}{c}\text { Food } \\
\text { specialization }\end{array}$ & Forage plants \\
\hline I & II & III & IV & $\mathbf{V}$ \\
\hline 1. & Cameraria ohridella & 2002 & Monophage & Aesculus hippocastanum L. \\
\hline 2. & Acizzia jamatonica & 2008 & Monophage & Albizia julibrissin Durazz. \\
\hline 3. & Aphis nerii & 2009 & Monophage & Nerium oleander L. \\
\hline 4. & Icerya purchasi & 2010 & Polyphage & $\begin{array}{l}79 \text { plant species, the most preferred } \\
\text { families Fabaceae (30) and Rosaceae } \\
\text { (109) }\end{array}$ \\
\hline 5. & Ceroplastes japonicus & 2010 & Polyphage & $\begin{array}{l}\text { Ilex aquifolium L., Laurus nobilis L., } \\
\text { Diospyros kaki L.f., Pyracantha } \\
\text { coccinea } \text { M. Roem. }\end{array}$ \\
\hline 6. & Corynthucha ciliate & 2012 & Monophage & $\begin{array}{l}\text { Platanus orientalis L., Platanus } \\
\text { hispanica } \text { Münchh. }\end{array}$ \\
\hline 7. & Chrysolina americana & 2012 & Oligophage & $\begin{array}{l}\text { Rosmarinus officinalis L., Lavandula } \\
\text { angustifolia Moench, Lavandin sp., } \\
\text { Salvia officinalis L. }\end{array}$ \\
\hline 8. & Bactrocera oleae & 2013 & Monophage & Olea europaea L. \\
\hline 9. & Cydalima perspectalis & 2015 & Monophage & $\begin{array}{l}\text { Buxus sempervirens L., Buxus } \\
\text { balearica Lam. }\end{array}$ \\
\hline 10. & Rhynchophorus ferrugineus & 2015 & Oligophage & Trachycarpus fortunei (Hook.) H. Wendl. \\
\hline 11. & Bruchidius terrenus & 2017 & Monophage & A. julibrissin \\
\hline 12. & Paysandisia archon & 2018 & Oligophage & $\begin{array}{l}\text { T. fortunei, Chamaerops humilis L., } \\
\text { Phoenix canariensis Chabaud }\end{array}$ \\
\hline 13. & Ophelimus maskelli & 2018 & Monophage & Eucalyptus calcicola Brooker \\
\hline 14. & Corythucha arcuata & 2019 & Monophage & Quercus sp. \\
\hline 15. & Halyomorpha halys & 2020 & Polyphage & Citrus, Prunus \\
\hline
\end{tabular}

\subsection{Cydalima perspectalis Walker}

For the first time it was identified on the territory of the Nikitsky Botanical Garden in June 2015 on Buxus sempervirens L. in skirting plantings and on individual plants. The population density was 8-10 individuals $/ \mathrm{m}^{2}$ of older caterpillars [5]. A study of the phenological rhythms of $C$. perspectalis, conducted in 2018-2020 on the South Coast and in the central foothill 
zone of the Crimea, showed that the pest develops in three generations, caterpillars of age II-III overwinter. The duration of each of three generations development is on average 4050 days. The exit of the caterpillars from the winter diapause is extended. It was found that $50 \%$ of the caterpillars start feeding at $\sum$ ef. $\mathrm{t}+16.2^{\circ} \mathrm{C}$ (above $+10^{\circ} \mathrm{C}$ ) [4]. In 2019, overwintered caterpillars were observed from the first decade of April to the first decade of June, when young caterpillars of a new generation already appeared. The constant presence of feeding caterpillars on plants is due not only to the extended exit from the winter diapause, but also to the asynchronous molting, born from a single oviposition (which was observed in each generation), as well as to the departure to the spring-summer diapause under unfavorable conditions. In 2020 , the increased temperatures in February $\left(5.3^{\circ} \mathrm{C}\right)$ and March $\left(16.0^{\circ} \mathrm{C}\right)$, significantly exceeding the long-term indicators $\left(2.3\right.$ and $\left.12.5^{\circ} \mathrm{C}\right)$, contributed to the earlier exit of the caterpillars from the winter diapause, namely, a month earlier - in the first decade of March.

The flight of the adult overwintered imago began in the third decade of May (at SET $>10$ $=210.8^{\circ} \mathrm{C}$ ) and lasted until the first decade of July. The development of the first generation was observed in the period from the first decade of July (at SET $>10=726.9^{\circ} \mathrm{C}$ ) to the second decade of August, while the development of the second generation occurred in the period from the third decade of July (at SET $>10=1042.2^{\circ} \mathrm{C}$ ) to the third decade of November, where the diapause was noted (at SET $>10=2148.5^{\circ} \mathrm{C}$ ) (Table 2).

It should be noted that from the pupae that pupated on April 11, the imago emerged on May 25-26 (the duration of the pupal stage is on average 45-46 days), while imago emergence was only $23.1 \%$, the rest of the pupae died. The butterflies emerged on May 31 (pupal stage44 days) from the pupae that pupated on April 18, the death rate at the pupal stage was $61.4 \%$. When pupating of caterpillars in May (II-III decades), the duration of the pupal phase was typical for the overwintered generation (14-20 days), and the emergence of viable imago was $90 \%$. Thus, the spring temperature changes in 2020 significantly reduced the number of imago of the overwintered generation.

Table 2. Phenological calendar of development of Cydalima perspectalis Walker, the Crimea, South Coast, village Nikita, 2020

\begin{tabular}{|c|c|c|c|c|c|c|c|c|c|c|c|c|c|c|c|c|c|c|c|c|c|c|c|}
\hline \multicolumn{3}{|c|}{ March } & \multicolumn{3}{|c|}{ April } & \multicolumn{3}{|c|}{ May } & \multicolumn{3}{|c|}{ June } & \multicolumn{3}{|c|}{ July } & \multicolumn{3}{|c|}{ August } & \multicolumn{3}{|c|}{ October } & \multicolumn{3}{|c|}{ November } \\
\hline I & II & III & I & II & III & I & II & III & I & II & III & I & II & III & I & II & III & I & II & III & I & II & III \\
\hline (C) & - & - & - & - & - & - & - & - & - & & & & & & & & & & & & & & \\
\hline & & & & $\overline{0}$ & 0 & $\mathbf{0}$ & 0 & $\overline{0}$ & $\overline{0}$ & $\mathbf{0}$ & & & & & & & & & & & & & \\
\hline & & & & & & & & + & + & \pm & + & + & & & & & & & & & & & \\
\hline & & & & & & & & 0 & 0 & 0 & 0 & 0 & & & & & & & & & & & \\
\hline & & & & & & & & & - & - & - & - & - & - & & & & & & & & & \\
\hline & & & & & & & & & & & & 0 & 0 & $\mathbf{0}$ & $\mathbf{0}$ & & & & & & & & \\
\hline & & & & & & & & & & & & & + & + & + & + & & & & & & & \\
\hline & & & & & & & & & & & & & 0 & 0 & 0 & 0 & & & & & & & \\
\hline & & & & & & & & & & & & & & - & - & - & - & - & & & & & \\
\hline & & & & & & & & & & & & & & & & & $\mathbf{0}$ & $\mathbf{0}$ & $\mathbf{0}$ & & & & \\
\hline & & & & & & & & & & & & & & & & & & + & + & + & & & \\
\hline & & & & & & & & & & & & & & & & & & 0 & 0 & 0 & & & \\
\hline & & & & & & & & & & & & & & & & & & - & - & - & - & - & (c) \\
\hline
\end{tabular}

Designation: + - imago; ${ }^{\circ}$ - egg; - - caterpillar; (C) - wintering caterpillar; 0 - pupa. 


\subsection{Cameraria ohridella Deschka\&Dimic}

On the territory of the Crimea, on the Southp Coast, the pest was discovered in 2002. The main forage plant for pest caterpillars is A. hippocastanum. [1]

It was found that during the growing season, phytophage ontogenesis occurs in 2-3 generations, depending on weather conditions. The appearance of the first single individuals occurs in the I decade of April at SET $>10=33.6^{\circ} \mathrm{C}$ and continues until the III decade of September - the I decade of October. The increase in numbers occurs in the II-III decade of May $\left(\mathrm{SET}>0=199.0-283.4^{\circ} \mathrm{C}\right)$, the III decade of June $\left(\mathrm{SET}>10=660.0^{\circ} \mathrm{C}\right)$ and the I decade of August (SET $>10=1271.0^{\circ} \mathrm{C}$ ). It was found that the dynamics of the C. ohridella population size directly depends on the temperature conditions (Figure 3). The correlation coefficient between the number and the average daily air temperature was $r=0.74$, and the relative humidity was $r=0.59$.

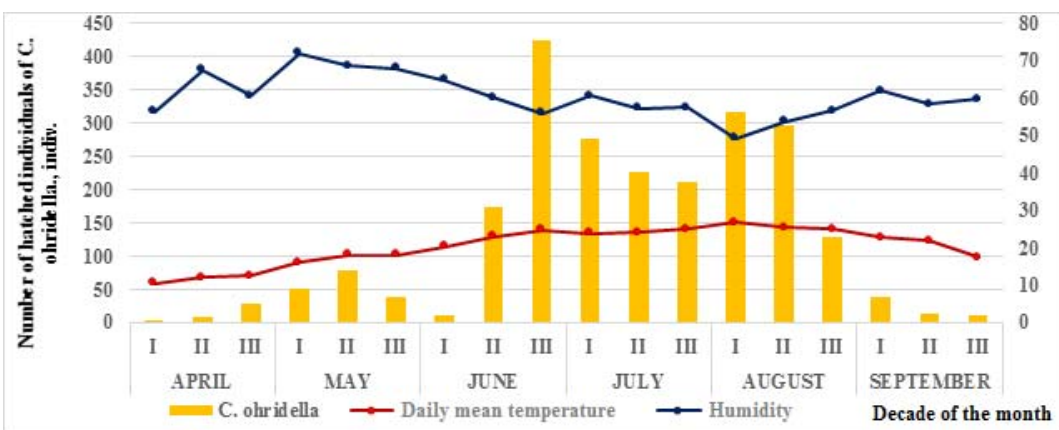

Fig. 3. Average long-term population dynamics C. Ohridella in the conditions of the South Coast of the Crimea, 2016 - 2020

\subsection{Icerya purchasi Mask}

The species was identified in 2010 on the territory of the arboretum of the Nikitsky Botanical Garden, the sanatorium "Ai-Danil" and in the village of Partenit (Alushta district) on Pittosporum tobira Ait., Pittosporum heterophyllum Franch., Spartium yunceum L., Hedera helix var. taurica Hibberd Nandina domestica Thunb, Albizia julibrissin Durazz., Lagerstroemia indica L., Lauracerasus lusitanica (L.) Roem, Cercis siliquastrum L., Citrus limon (L.) Burn.

Pest colonies inhabit trunks, skeletal and thin branches, leaves and fruits. The colony may contain from 5 to 12 red-colored females in a dense chitinous cover with vertically arranged hairs. Egg laying takes place in egg pouches - "ovisacks", which have a natural protection that preserves the egg-laying and hatched larvae from the effects of adverse environmental conditions. Currently, I. purchasi has been recorded on 79 plant species. The preferred plants are of Fabaceae and Rosaceae families. The phytophage develops according to a nonspecialized cycle (the number of generations is not constant and depends on weather conditions). On the South Coast of the Crimea in 2019, 3 generations were recorded, while in $2020-4$ (Table 3).

In the parks of the region, 211 foci of mass $I$. purchasi reproduction were identified, incl. in 2020 it increased by 165 foci (78\%) compared to the data of 2019. I. Purchasi was recorded on plants of the following life forms: deciduous trees - 17 species; deciduous shrubs -27 ; evergreen trees - 7; coniferous trees - 1; evergreen shrubs - 19; herbaceous plants - 8 . Based on the analysis of the results obtained, it can be predicted that the list of forage plants in the parks and urban plantings of the South Coast of the Crimea will increase by another 200 plant species. 
Table 3. The phenological calendar of I. purchasi. the South Coast of the Crimea, village Nikita, 2020

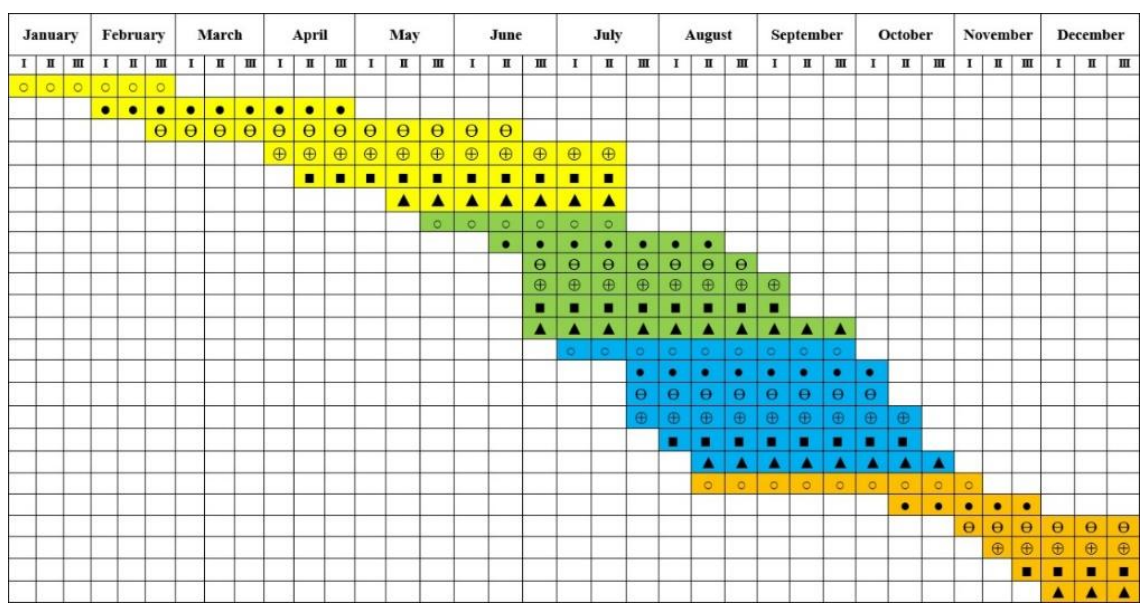

Designations: o - egg; • - larvae of the age I; $\Theta$ - larvae of the age II; $\oplus$ - larvae of the age III; $\mathbf{~ - ~}$ nymphs; $\sigma$ - imago.

\subsection{Ceroplastes japonicus Green}

On the South Coast of the Crimea, it was first discovered in 2010 on Laurus nobilis L. and Ilex aquifolium L. Currently, the most widespread phytophage development is noted on $L$. nobilis, D. kaki, I. Aquifolium, Pistacia mutica Fisch.\& C.A. Mey and Pyracantha coccinea M. Roem. The pest infests skeletal branches with large colonies and leaves on the upper side with single individuals. It is established that the number of pests in one colony per 10 lin. $\mathrm{cm}$ of shoots can reach up to 20 individuals, on the leaves on average from 1 to 4 individuals. Older larvae overwinter. The reproduction capability of one female averages 376-402 eggs. One generation per year is recorded. The appearance of eggs in 2019 was recorded in April, the development of larvae began in June, females - in October. It is known that $C$. japonicus diapauses in the female stage. [9] It was found that in the conditions of the South Coast of the Crimea, in the winter period from 2020 to 2021, not only females, but also larval stages of the age II overwinter (Figure 4.). In 2020, eggs were recorded in June, larvae - in August, and females - in November. The nature of the damage is similar to the destructive activity of I. purchasi.

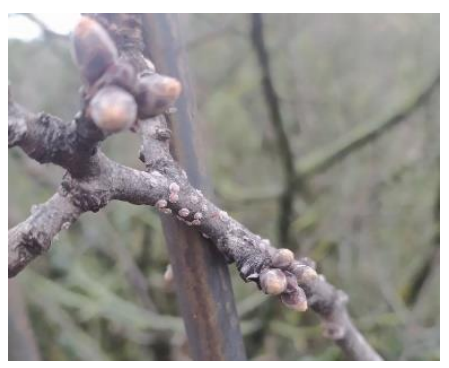

Fig. 4. Diapausing larvae of C. japonicus of age II (L2) on P. mutica. the Crimea, village Nikita, 2021 Original photo. 


\subsection{Paysandisia archon Burmeister.}

The spring-summer survey of parks in 2019 allows to conclude that there are two foci of $P$. archon displacement on the shore of the South Coast of the Crimea (city of Alupka, village Simeiz and Alushta, village Partenit). In the area of the village of Simeiz, P. archon was recorded for the first time in 2017 in the fall, on the territory of the city of Alupka and in the village of Partenit in 2018. The characteristic external signs of pest infestation of plantings of the Trachycarpus genus indicate a natural latent invasion of $P$. archon for 2-3 years. Thus, it can be assumed that the colonizer penetrated the Black Sea coast of the Crimea with planting material in 2013-2014. The palm trees of the genera Chamaerops, Trachycarpus, Washingtonia, Livistona, Phoenix, and Sabal are among the forage preferences of P. archon. The hatched caterpillars penetrate into the trunk and feed on the wood there, boring through numerous galleries of passages, soaking the shoots, perforating the leaves, completely destroying the core and destroying the point of growth of the palm. Even with a small population of palm tree trunk by caterpillars, their activity leads to the aberrant development of axil leaf buds and the appearance of deformed shoots. In addition, the pest contributes to the appearance of secondary infections, thereby accelerating the process of palm tree death. The species is highly aggressive. The main danger is that the damage is almost invisible until the palm tree dies. Since the eggs are laid on several nearby palm trees, there is often a group death of plants. $[3,8]$

It should be noted that in Europe, P. archon is currently included in the EPPO A2 List, i.e. it belongs to the quarantine species that are limitedly distributed in Europe.

\section{Conclusions}

As a result of a long-term analysis of the phytosanitary condition of the parks, its instability was revealed, which is expressed in periodic sharp increases in the number of individual pests, disappearance of others, constant changes of the dominant species that occur under the influence of interspecific competition, weather and climatic factors, anthropogenic and pesticide loads, the activity of entomo-acariphages and passive migration.

Since the beginning of the active introduction of woody and shrubby plants of foreign breeding in the Crimea since the beginning of the 2000s, 15 phytophages not previously registered in the territory of the Crimea have been identified over an 18-year period, of which 9 species are monophages, 3 species are oligophages and 3 species are polyphages. At the same time, since 2008, 1-2 new species have been registered annually.

Due to the introduction of alien species, the taxonomic structure of the entomo-acariphage complex of the parks of the South Coast of the Crimea has undergone significant changes. At present, invasive species are represented by five orders, of which $26.4 \%$ are species of the order Homoptera, $19.8 \%$ are species of the orders Lepidoptera, Coleoptera and Hymenoptera, $14.2 \%$ are phytophages of the order Diptera. I. purchasi, $C$. perspectalis, $C$. japonicus, $C$. americana, $C$. ohridella, $B$. oleae and $P$. archon are greatest threats to plantings. These phytophages were able to adapt well in a mild climate and, in the absence of natural restraining factors, continue to disseminate in the South Coast zone, displacing native species.

In general, the research results confirm once again the importance and relevance of studying the role of invasions of non-indigenous organisms in the formation of biological diversity. 


\section{References}

1. V.V. Anikin, E.N. Kondratyev, Entomological and parasitological studies in the Volga region, 17, 91 (2020)

2. V.P. Isikov, N.N. Trikoz. Phytosanitary monitoring in park plantations of the Crimea, 300 (2019)

3. N.N. Karpun, E.N. Zhuravleva, L.A. Ayba, E.B. Balykina, Recommendations for identifying stem pests of palm trees and measures to combat them, 43 (2019)

4. Yu.V. Plugatar, A.K. Sharmagiy, E.B. Balykina, Bulletin of Plant Protection, 103(4), 247 (2020)

5. N.N. Trikoz, Z.E. Khalilova, Collection of scientific works of the State Nikitsky Botanical Garden, 142, 69 (2016)

6. N.N. Trikoz, E.V. Yatskova, Bulletin of the State Nikitsky Botanical Garden, 134, 130 (2020)

7. S. Khokhlov, V.A. Melnikov, E.S. Panyushkina, E. Balikina, Acta Horticulturae, 1255, 179 (2019)

8. R. Delle-Vedove, L. Beaudoin-Ollivier, M. Hossaert-Mckey, B. Fréro, Eur. J. Entomol, 109(2), 289 (2012)

9. T. Masten-Milek, G. Seljak, M. Šmala, Proceedings of the 8th Slovenian Post Conference on Plant Protection, Radenci, Slovenia, 6-7, 330 (2007) 